\title{
First estimates of population ecology and threats to Sunda clouded leopards Neofelis diardi in a peat-swamp forest, Indonesia
}

\author{
Susan M. Cheyne ${ }^{1,2, *}$, Danica J. Stark ${ }^{3}$, Suwido H. Limin ${ }^{4}$, David W. Macdonald ${ }^{1}$ \\ ${ }^{1}$ Wildlife Conservation Research Unit (WildCRU), Department of Zoology, Oxford University, The Recanati-Kaplan Centre, \\ Tubney House, Abingdon Road, Tubney OX13 5QL, UK \\ ${ }^{2}$ Orang-utan Tropical Peatland Project, Jalan Semeru No. 91, Bukit Hindu, Palangka Raya, Indonesia \\ ${ }^{3}$ Cardiff School of Biosciences, Cardiff, University, Biomedical Sciences Building, Museum Avenue, Cardiff CF10 3AX, UK \\ ${ }^{4}$ Centre for the International Cooperation in Management of Tropical Peatlands (CIMTROP), \\ University of Palangka Raya, Indonesia
}

\begin{abstract}
The Sunda clouded leopard Neofelis diardi is Borneo's largest predator. A study of the species' population ecology in $50 \mathrm{~km}^{2}$ (effective sample area $145 \mathrm{~km}^{2}$ ) of the Sabangau forest, Central Kalimantan, Indonesia, spanned May 2008 to January 2012. A total of 54 camera traps at 27 stations yielded 35129 functional trap nights resulting in 90 photos of 6 clouded leopards: 5 males and 1 female. Using capture-recapture analysis in 3 mo blocks, we extrapolated to an estimated density range of 0.72 to 4.41 ind. per $100 \mathrm{~km}^{2}$ across all models and all data sets. Direct hunting pressure on the cats and indirect threats through possible depletion of the prey base by humans were assessed though interview and questionnaire surveys of 68 villagers in 9 villages around the edge of the $5600 \mathrm{~km}^{2}$ Sabangau Forest. Of the respondents, $40 \%$ hunted deer and bearded pigs, although no respondent listed hunting as their main source of income or food. The low detection rates of clouded leopards suggests that a minimum area of $100 \mathrm{~km}^{2}$ per site, and multiple sites, should be studied to elucidate the impact of habitat disturbance and fragmentation on clouded leopard populations.
\end{abstract}

KEY WORDS: Camera trapping $\cdot$ Capture-recapture $\cdot$ Predator $\cdot$ Hunting

\section{INTRODUCTION}

The Bornean tropical forest contains an assemblage of 5 felid species: Sunda clouded leopard Neofelis diardi (Vulnerable), bay cat Pardofelis badia (Endangered), marbled cat P. marmorata (Vulnerable), flat-headed cat Prionailurus planiceps (Endangered) and leopard cat Prionailurus bengalensis (Least Concern) (IUCN 2008). Research on this assemblage in Borneo provides the chance to study clouded leopard in the absence of competitors such as tigers Panthera tigris and large canids (Cheyne \& Macdonald 2011).
No reliable population data are available for felids in Indonesian Borneo, and the impact of human disturbance on their populations is poorly understood (Wilting et al. 2006, 2010, Povey et al. 2009, Cheyne \& Macdonald 2011). Peat-swamp forests are amongst the largest contiguous forest blocks in lowland Indonesian Borneo (Page et al. 1997, Shepherd et al. 1997) and are threatened by habitat loss and conversion (Koh \& Wilcove 2007). The IUCN Red List 2008 (IUCN 2008) calls for research on population size and basic ecology of the Sunda clouded leopard.

The sparse evidence available suggests that wild populations of 4 of the 5 Bornean felids are declining 
based on the assumption that they are all forestdependent to some degree and that overall forest cover across Borneo is declining (Rautner 2005, Wilting et al. 2006, Povey et al. 2009, A. J. Hearn et al. unpubl. data, J. Ross et al. unpubl. data). Extrapolating from estimates of density and geographic range, the total effective population size (Borneo and Sumatra) of the Sunda clouded leopard has been estimated at $<10000$ individuals, and no sub-population is thought to contain $>1000$ individuals (IUCN 2008). The clouded leopard may be a complementary flagship and umbrella species to the apes, as they may persist at lower densities, require larger areas of habitat and a sufficient prey base (Johns 1985, 1988, Burnham et al. 2013).

The perceived decline of clouded leopard populations is generally attributed to a familiar syndrome of human disturbances: habitat degradation and fragmentation and hunting (direct and indirect). Previous studies have found that clouded leopards were killed as by-catch of hunting for pigs, deer and monkeys (Rabinowitz et al. 1987, Wilting et al. 2006) or to obtain the pelts for ceremonial use (Rabinowitz et al. 1987, Nowell \& Jackson 1996, Povey et al. 2009). Their teeth are also highly prized, and their bones and organs are sometimes used in traditional medicine (Shepherd \& Nijman 2008). In addition, some restaurants were found to serve clouded leopard, reputedly catering to wealthy Asian tourists (Rabinowitz et al. 1987). Our aims were to identify individual clouded leopards and residence time in the study area, to investigate threats and behavioural ecology and, using rates of capture and recapture, to assess their population density in Sabangau peat forest.

\section{MATERIALS AND METHODS}

\section{Study site}

The study was carried out in the Natural Laboratory for peat-swamp forest in the north-eastern corner of the Sabangau Forest $\left(2^{\circ} 19^{\prime} \mathrm{S}\right.$ and $113^{\circ} 54^{\prime} \mathrm{E}$, Fig. 1). This area covers $50 \mathrm{~km}^{2}$ of the total $5600 \mathrm{~km}^{2}$ of forest.

The area is operated by the Centre for International Cooperation in Management of Tropical Peatlands (CIMTROP). Sabangau is the largest contiguous lowland rainforest remaining in Kalimantan and is recognised as one of the most important conservation areas in Borneo, for a variety of reasons including carbon storage, regulation of water supplies and

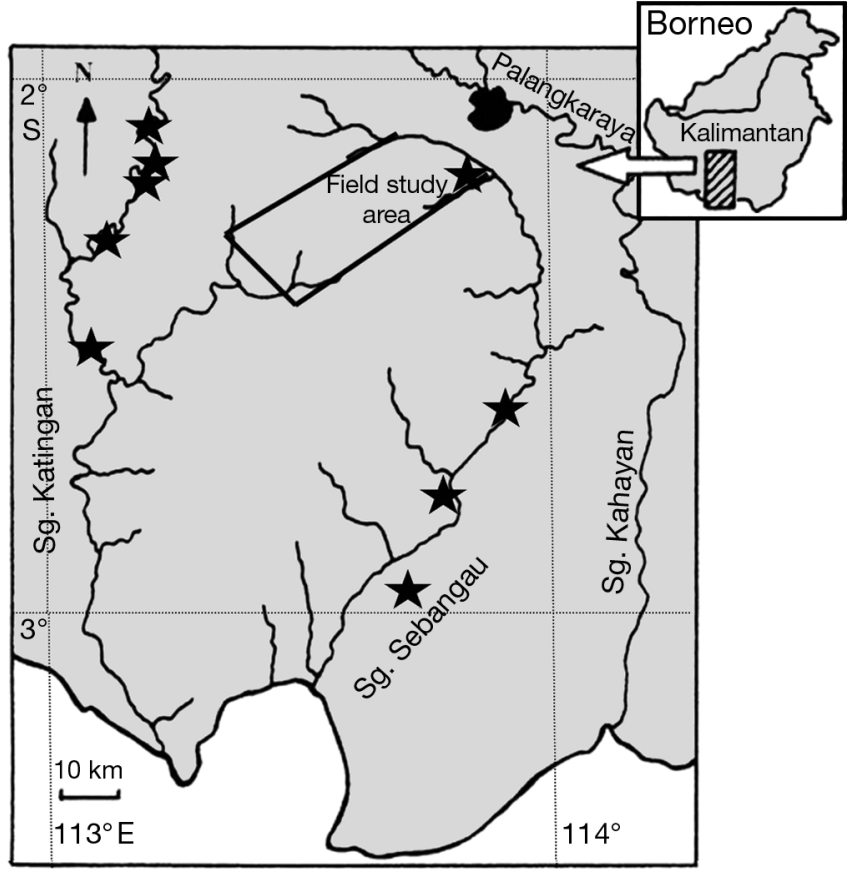

Fig. 1. Study site (black box) in the Sabangau Forest, Indonesia. Locations of villages where the questionnaire surveys were carried out are indicated by stars

conservation of flora and fauna (Aldhous 2004). The area has been subjected to long-term legal logging, illegal logging, fire and drainage from logging canals, but is now the focus of concerted protection and restoration efforts (Morrogh-Bernard et al. 2003, Cheyne 2010).

The Sabangau area is one of the deepest peatswamp forests in the world, with peat ranging from 3 to $26 \mathrm{~m}$ (Page et al. 1999). Clouded leopard, leopard cat, flat-headed cat and marbled cat occur there (Cheyne \& Macdonald 2011). Logging and fire have resulted in a patchwork of logged, recovering and pristine forest covering 4 habitat subtypes (mixed-swamp forest, transitional/mixedswamp forest, low interior forest, tall interior forest; Page et al. 1999).

\section{Cameras}

From May 2008 to January 2012, 54 camera traps were set in fixed forest areas to investigate diversity, relative abundance and activity patterns of Bornean wild cats (Table 1).

In total, 20 Cuddeback Expert ${ }^{\circledR}$ and 34 Cuddeback Capture IR ${ }^{\circledR}$ (Cuddeback Digital, Non-Typical) camera traps were placed along established humanmade trails (primarily $>4 \mathrm{yr}$ old) and, where possi- 
Table 1. Characteristic sample effort for each study location within Sabangau. Trap nights exclude non-active nights. The main study site (Grid) was the focus of the work and hence has significantly more survey effort. Other areas were limited by access, size of area and number of available cameras to complete the surveys and hence were only surveyed for short periods. This allowed cameras to be used across multiple sites Dates are given as dd/mm/yy

\begin{tabular}{|lccccccc|}
\hline $\begin{array}{c}\text { Survey } \\
\text { area }\end{array}$ & $\begin{array}{c}\text { No. paired } \\
\text { stations } \\
\text { (no buffer) }\end{array}$ & $\begin{array}{c}\text { Area } \\
\left(\mathrm{km}^{2}\right)\end{array}$ & $\begin{array}{c}\text { Days } \\
\text { active }\end{array}$ & $\begin{array}{c}\text { Trap } \\
\text { nights }\end{array}$ & Date set & $\begin{array}{c}\text { Date } \\
\text { removed }\end{array}$ & $\begin{array}{c}\text { Clouded } \\
\text { leopards } \\
\text { detected }\end{array}$ \\
\hline Canal I & 6 & 3 & 50 & 300 & $04 / 06 / 09$ & $23 / 07 / 09$ & $\mathrm{~N}$ \\
Grid & 31 & 9 & 1014 & 31434 & $15 / 05 / 08$ & $21 / 01 / 12$ & $\mathrm{Y}$ \\
Jelutong & 6 & 3 & 50 & 300 & $04 / 08 / 09$ & $22 / 09 / 09$ & $\mathrm{~N}$ \\
Koran & 5 & 3 & 499 & 2495 & $09 / 11 / 10$ & $14 / 04 / 11$ & $\mathrm{~N}$ \\
Grid and & 6 & 50 & 100 & 600 & $10 / 10 / 11$ & $31 / 01 / 12$ & $\mathrm{Y}$ \\
$\quad \begin{array}{l}\text { Tall Pole } \\
\text { Total }\end{array}$ & 54 & & & 35129 & & & \\
\hline
\end{tabular}

ble, watering areas, located so as to maximise the success rate of photographic 'detections' (Wilting et al. 2006, Gordon \& Stewart 2007). Two cameras were placed opposite each other, 7 to $10 \mathrm{~m}$ apart to create a paired station at each location with the aim of photographing each flank of the animal simultaneously. The passive infrared sensor was set at about $50 \mathrm{~cm}$ height. The Expert cameras have a pre-set minimum of $60 \mathrm{~s}$ delay between triggers, and used a white flash, whereas the Captures use an infrared flash. The infrared cameras have no white-light flash, and this was deemed better for long-term use to avoid potential trap shyness from flash photography (Rowcliffe \& Carbone 2008, Rowcliffe et al. 2008). There are no logging roads in the study area, and all cameras were placed along established trails at cross-roads and near fallen logs or man-made boardwalks, which may facilitate felid movements during the flooded wet season. Only 2 of 22 stations were on newly cut trails, the remainder being sited on established trails 0.5 to $1.0 \mathrm{~km}$ apart. No bait or lure was used, and batteries were changed every $14 \mathrm{~d}$. All cameras were placed 0.5 to $5 \mathrm{~km}$ from the forest edge in previously logged mixed-swamp forest with 1 pair in the mixedswamp/transitional forest $5 \mathrm{~km}$ from the forest edge (farthest accessible point). Cameras were not placed in the deforested areas, which had been burnt, lacked canopy cover and were inaccessible. To prevent damage by sun bears Helarctos malayanus and by pig-tailed macaques Macaca nemestrina, and to enable more precise placement of cameras, all cameras were placed in protective boxes supported by a single wooden leg. No differences were found between the infrared and white flash cameras, and these were also never paired together.

\section{Analysis of CAPTURE data}

We followed the example of Lynam et al. (2009) and used a capturerecapture approach (White et al. 1982); a web-based version of Program CAPTURE (Otis et al. 1978, White et al. 1982) was employed to estimate numbers of clouded leopards present at each site. In Program CAPTURE we ran 2 population models: the first assumes equal probabilities of capture for individuals (known as the null population model, $\mathrm{M}_{0}$ ) and the second assumes heterogeneous probability of detection of individuals (known as the jack-knife population model, $\mathrm{M}_{\mathrm{h}}$ White et al. 1982). Due to the very small sample sizes, we followed the recommendations of White et al. (1982) and Lynam et al. (2009) and estimated a $95 \%$ CI as $\widehat{N} \pm 1.96$ SE (where $\widehat{N}$ is estimated abundance) and then rounded up to the nearest whole integer to get the upper limit, and rounded down to the nearest whole integer to get the lower limit. If the lower limit was less than the number of individuals caught $\left(N_{\mathrm{CI}+1}\right)$, we then used $N_{\mathrm{CI}+1}$ as the lower $95 \%$ CI (White et al. 1982).

No distinction was made between males and females. To avoid violating the assumptions of closed populations, the data were split into blocks of $3 \mathrm{mo}$ (Table 2). Only the locations where clouded leopards were detected on the cameras were used for this analysis, i.e. Grid and Grid + Tall Pole (Table 1). Based on the total number of cats detected and the maximum number of recaptures, 3 blocks were selected for analysis. Block 6 represents the block with the highest number of individual cats, Block 9 the block with the lowest number of individual cats, and Block 15 the block with the largest continuous survey area. These blocks represent (1) the minimum number of cats and recaptures in the core study area, (2) the maximum number of cats and recaptures in the core study area and (3) the largest continuous area surveyed.

\section{Estimating density from CAPTURE data}

In the absence of telemetry data, various ad hoc approaches can be used to estimate animal range sizes and hence to estimate the area trapped. The effective trapping area is a combination of the total trapping area with a buffer to estimate the area sur- 
Table 2. Neofelis diardi. Each closed-population survey block is shown with the ID of each individual captured in this period (Males M1-5 and Female F1), the total individuals detected, total photo detections (dtns) of all individuals and the number of re-detections

\begin{tabular}{|c|c|c|c|c|c|c|c|c|c|c|c|c|}
\hline Block & $\begin{array}{l}\text { Survey } \\
\text { area }\end{array}$ & Start date & End date & M1 & M2 & M3 & M4 & M5 & F1 & $\begin{array}{l}\text { No. } \\
\text { ind. }\end{array}$ & $\begin{array}{l}\text { Total } \\
\text { dtns }\end{array}$ & $\begin{array}{l}\text { Total } \\
\text { re-dtns }\end{array}$ \\
\hline 1 & Grid & May 2008 & Jul 2008 & 1 & 0 & 0 & 0 & 0 & 0 & 1 & 1 & 0 \\
\hline 2 & Grid & Aug 2008 & Oct 2008 & 3 & 6 & 0 & 0 & 0 & 0 & 2 & 9 & 7 \\
\hline 3 & Grid & Nov 2008 & Jan 2009 & 0 & 3 & 0 & 0 & 0 & 0 & 1 & 3 & 2 \\
\hline 4 & Grid & Feb 2009 & Apr 2009 & 2 & 0 & 0 & 0 & 0 & 0 & 1 & 2 & 0 \\
\hline 5 & $\begin{array}{l}\text { Grid + } \\
\text { Canal I }\end{array}$ & May 2009 & Jul 2009 & 0 & 1 & 0 & 0 & 0 & 0 & 1 & 1 & 0 \\
\hline $6^{\mathrm{a}}$ & $\begin{array}{l}\text { Grid + } \\
\text { Jelutong }\end{array}$ & Aug 2009 & Oct 2009 & 1 & 6 & 0 & 0 & 1 & 2 & 4 & 10 & 6 \\
\hline 7 & Grid & Nov 2009 & Jan 2010 & 0 & 2 & 1 & 0 & 2 & 0 & 3 & 5 & 2 \\
\hline 8 & Grid & Feb 2010 & Apr 2010 & 1 & 0 & 0 & 0 & 0 & 0 & 1 & 1 & 0 \\
\hline $9^{a}$ & Grid & May 2010 & Jul 2010 & 0 & 5 & 0 & 0 & 0 & 0 & 1 & 5 & 4 \\
\hline 10 & Grid & Aug 2010 & Oct 2010 & 0 & 0 & 2 & 3 & 0 & 0 & 2 & 5 & 3 \\
\hline 11 & $\begin{array}{c}\text { Grid + } \\
\text { Koran }\end{array}$ & Nov 2010 & Jan 2011 & 0 & 1 & 2 & 2 & 1 & 0 & 4 & 6 & 2 \\
\hline 12 & $\begin{array}{c}\text { Grid + } \\
\text { Koran }\end{array}$ & Feb 2011 & Apr 2011 & 0 & 0 & 1 & 2 & 1 & 0 & 3 & 4 & 1 \\
\hline 13 & Grid & May 2011 & Jul 2011 & 0 & 1 & 1 & 1 & 0 & 0 & 3 & 3 & 0 \\
\hline 14 & Grid & Aug 2011 & Oct 2011 & 0 & 0 & 1 & 0 & 0 & 0 & 1 & 1 & 0 \\
\hline $15^{\mathrm{a}}$ & $\begin{array}{c}\text { Grid and } \\
\text { Tall Pole }\end{array}$ & Nov 2011 & Jan 2012 & 0 & 3 & 0 & 0 & 5 & 0 & 2 & 8 & 6 \\
\hline
\end{tabular}

areas between cameras, which would result in a 0 probability of capture. The abundance estimates were then used to estimate the clouded leopard densities, defined as $\widehat{D}=N / A$, where $N$ is animal abundance and $A$ is the effective surveyed area sampled.

\section{Hunting surveys}

Questionnaire-based surveys were carried out in 9 villages on the Sabangau River (eastern side of the research site) to investigate the extent of direct removal of clouded leopards and/or the indirect impact on the species' abundance of humans hunting clouded leopards' prey. Data were compiled from 37 families and a total of 68 respondents from different households between May 2009 and July 2010. The research samples were derived

veyed as accurately as possible (Karanth \& Nichols 1998). Previous studies calculating the buffer width based on distance moved by the animals have resulted in an over-estimation of the density due to incomplete data about distance moved (Silver et al. 2004, Soisalo \& Cavalcanti 2006). Following Wilting et al. (2006), we used a modified equation to calculate the buffer width:

$$
W=\frac{\frac{\sqrt{C}}{2}+\bar{\alpha}(M)}{2}
$$

where $C$ is the core area of home range sizes and $M$ is the average daily movement. The value for $C$ (= $6 \mathrm{~km}^{2}$ ) was obtained from Grassman et al. (2005) in Phu Khieo Wildlife Sanctury, Thailand, which is similar to the recent data from Hearn et al (2013) of $50 \%$ MCP of $5.2 \mathrm{~km}^{2}$ and $50 \%$ fixed kernel of $5.4 \mathrm{~km}^{2}$ from Sabah. Data for $M$ were obtained from the movement of the clouded leopards in this study ( $M$ for Blocks 6 and $9=1.74 \mathrm{~km}$ and for Block $15=3.35 \mathrm{~km})$. A strip of width $W$ was added to the convex hull (minimum convex polygon) of the trap sites (i.e. the polygon which bounds the outer traps). Following Maffei et al. (2005), it is preferable to add a circle of radius $W$ around each camera trap and then calculate the area bounded by the merged perimeter. This 'concave' approach reveals whether there are any 'unsampled' using non-probability quota sampling (Kerlinger 1986). The method was chosen to obtain an equally distributed sample over 5 different categories which were divided by age class (20-39 yr, $>40 \mathrm{yr})$ and gender, and 1 category was for local 'governmental employees' such as the village head. Age classes were established after consulting with several community members how the age-line (i.e. at what point people are considered 'young adult', 'middle-aged' or 'elderly') was defined within the villages, and the 'young adult' and 'middle-aged' classes were combined.

Questionnaires represented individual opinions and were adapted to local conditions by using information gained from informal and semi-structured interviews. Before starting the sampling process in the villages, successive refinements of the questionnaire were tested 3 times on Indonesian students to identify any questions which could bias the responses. To avoid bias, respondents were selected to come from different households, i.e. although some members of the same extended family were interviewed, they represented independent economic households. Furthermore, different households were selected to cover a wide range of different social levels. The questionnaires contained open as well as closed questions. For some issues, the contingent ranking method (Chambers 1994) was applied 
(e.g. to determine the relative importance of different forest resources for people's livelihood). Thus, each respondent was asked, for example, to choose the 5 most important aspects for their personal life. Afterwards the aspects were written on small cards and the respondent was asked to arrange them in ascending order of importance. Respondents were asked about all hunting activities to determine their impact on the natural community of which clouded leopards and their prey were part. Respondents were asked to rate their perception of availability of animals hunted by humans over a period of $10 \mathrm{yr}$ to account for possible depletion of prey in any given area. All data were collected by Indonesian researchers without foreign presence. Previous studies on which the questionnaire was based (Harrison et al. 2011) found a good correlation between reported hunting numbers and numbers of flying foxes in markets; thus we have no reason to suspect that answers were untruthful.

\section{RESULTS}

\section{Population analysis}

A summary of the 6 clouded leopards is presented in Table 3. All individuals were captured on camera more than once, but the female was detected at 2 stations and was only present in October 2009. This location was visited by only 1 of the males (M2) on 1 occasion, so despite $4 \mathrm{yr}$ of data, the movements of female clouded leopards in this site remain unknown. Ten of the 27 stations yielded photos of clouded leopards. The maximum distance moved (i.e. farthest distance between cameras on which the individuals were caught) by a single individual was $10.8 \mathrm{~km}$; this distance was covered by 2 males (M2 and M5).

Table 4. Neofelis diardi. Parameter estimates (with SE) from CAPTURE models of camera trapping data of Sunda clouded leopards in Sabangau Forest. Number of occasions refers to the number of times any clouded leopard was captured during this sample period. $\mathrm{M}_{\mathrm{h}}$ : jack-knife population model; $\mathrm{M}_{0}$ : null population model

\begin{tabular}{|lcccc|}
\hline Parameter & Abbreviation & Block 6 & Block 9 & Block 15 \\
\hline Effective area surveyed (incl. buffer; km $\left.{ }^{2}\right)$ & $\mathrm{A}$ & 80 & 80 & 145 \\
Probability of capture under $\mathrm{M}_{\mathrm{h}}$ & $\mathrm{p}$ & 0.33 & 0.33 & 0.23 \\
Closure test & $\mathrm{P}$ & 0.4 & 0.4 & 0.5 \\
Selection criteria & $\mathrm{M}_{\mathrm{o}}$ & 1 & 0.89 & 1 \\
Selection criteria & $\mathrm{M}_{\mathrm{h}}$ & 0.89 & 10 & 0.89 \\
No. occasions & $\mathrm{T}$ & 5 & 5 & 8 \\
No. individuals caught & $\mathrm{M}_{\mathrm{t}+1}$ & 1 & 5 & 2 \\
Total captures-recaptures & $\mathrm{n}$ & 8 & 0.11 & 8 \\
Probability of $\geq 1$ detection & $\mathrm{p} 1$ & 0.11 & 0.11 \\
Estimated no. leopards by $\mathrm{M}_{0}$ & $\widehat{N}(95 \% \mathrm{CI})$ & $1.00 \pm 0.37(1-2)$ & $2.00 \pm 0.64(2-5)$ & $2.00 \pm 0.15(2-2)$ \\
Estimated no. leopards by $\mathrm{M}_{\mathrm{h}}$ & $\widehat{N}(95 \% \mathrm{CI})$ & $2.00 \pm 0.44(2-5)$ & $3.00 \pm 0.53(2-6)$ & $2.00 \pm 0.95(2-4)$ \\
\hline
\end{tabular}


1.05 to 3.53 individuals (Table 4 ). The CAPTURE analysis estimated that clouded leopard densities fall within the range 0.72 to 4.41 individuals $100 \mathrm{~km}^{-2}$ (Table 5).

\section{Hunting (direct and indirect)}

A total of 68 respondents from 9 villages ranged in age from 23 to $52 \mathrm{yr}$. All respondents were male, as hunting is a male-dominated activity. The main sources of income were farming (15\% of respondents), fishing $(50 \%)$ and private $(35 \%)$. No one listed hunting as their main source of income. Despite this, 10 to $20 \%$ of the population of each village engaged in hunting in any one month: the main method used was dogs and spear, with snares being the next most common. Animals targeted were: deer (Sambar deer Rusa unicolor and greater and lesser mouse deer, Tragulus napu and T. kanchil, which corresponds to $20 \%$ of respondents catching an average of 1 to 2 animals per hunting trip; bearded pig Sus barbatus corresponding to $20 \%$ of respondents catching an average of 1 animal trip ${ }^{-1}$; fish (blackwater species) corresponding to $40 \%$ of respondents catching an average of 1 to 20 animals trip ${ }^{-1}$, and flying fox Pteropus vampyrus natunae corresponding to $20 \%$ of respondents catching an average of 1 to 40 animals trip ${ }^{-1}$. The perceived availability of animals for hunting over the last $10 \mathrm{yr}$ varied: bearded pigs and deer were deemed to be stable, while fish and flying fox catches were listed as declining.

The interviews revealed that all 68 individuals engaged in hunting, on average about once a month. Availability of deer species and bearded pigs was not deemed to have declined or increased, but the availability of fish and, especially, flying foxes was perceived to have declined. Flying foxes especially have suffered a marked (and documented) decline (Strue-

Table 5. Neofelis diardi. Spatial parameters and clouded leopard density estimates during 3 survey periods using buffer widths calculated following Wilting et al. (2006) and based on $\mathrm{M}_{0}$ : null population model, $\mathrm{M}_{\mathrm{h}}$ : jack-knife population model

\begin{tabular}{|lcccc|}
\hline $\begin{array}{l}\text { Site } \\
\text { (no. leopards) }\end{array}$ & $\begin{array}{c}\text { Buffer } \\
\text { distance } \\
(\mathrm{km})\end{array}$ & $\begin{array}{c}\text { Effective } \\
\text { sample area } \\
\left(\mathrm{km}^{2}\right)\end{array}$ & \multicolumn{2}{c|}{ Density (ind. 100 $\left.\mathrm{km}^{-2}\right)$} \\
$\mathrm{M}_{0}$ & $\mathrm{M}_{\mathrm{h}}$ \\
\hline Block 6 (1) & 1.74 & 80 & $0.84-1.71$ & $2.08-3.05$ \\
Block 9 (4) & 1.74 & 80 & $1.70-3.30$ & $3.09-4.41$ \\
Block 15 (2) & 3.35 & 145 & $1.28-1.48$ & $0.72-2.03$ \\
\hline
\end{tabular}

big et al. 2007, Harrison et al. 2011). The majority of hunting was either for bush meat or for the pet trade. Song birds and owls (e.g. Malay fish owl Ketupa ketupu and brown wood owl Strix leptogrammica) were targeted for sale as pets. Of species hunted for bush meat, fish were hunted by $40 \%$ of respondents, deer (Sambar deer and greater and lesser mouse deer Tragulus napu and T.kanchil) and bearded pig were hunted by $40 \%$ of respondents, and flying fox was hunted by $20 \%$ of respondents. No mention was made of the pangolin Manis javanica, which is hunted in the region for its scales, which are used in traditional Chinese medicine (Pantel \& Yun 2009). In addition, hunting did not occur every month but rather seasonally, and most frequently in the dry season months (June to September) when access to the forest is easier. Respondents were asked to list all species which were hunted for any purpose, and no mention of felids was made, either as targeted species, opportunistically hunted species or species which may be killed as competitors for the deer and bearded pigs. The vast majority of local people are not aware of the protected status of all felids in Borneo and so would have few reservations about being truthful. Similar questionnaires used in the highlands of Indonesian Borneo have elicited responses that felids (clouded leopards and leopard cats) are hunted for their pelts and because the cats attack chickens (Cheyne et al. 2012), so we have no reason to suspect that respondents in this study were deliberately not mentioning the hunting of felids.

\section{DISCUSSION}

\section{Density}

Sabangau is a peat swamp forest, a habitat in which Sunda clouded leopards have not previously been studied, and which it was predicted that they would inhabit at low density, if at all, in accordance with the low productivity of this type of ecosystem (Page et al. 1997, Cheyne et al. 2008). We found an estimated density range of 0.72 to 4.41 individuals per $100 \mathrm{~km}^{2}$ using data from Blocks 6, 9 and 15 and from the $M_{0}$ and $M_{h}$ models. Other studies using different modelling approaches to generate their estimates (and often different field methods as well) have obtained different estimates (Table 6). 
Table 6. Neofelis diardi. Comparison of Sunda clouded leopard population densities (ind. $100 \mathrm{~km}^{-2}$ ) from Borneo. 'Whole area' includes logged forest. SECR: spatially explicit capture-recapture

\begin{tabular}{|c|c|c|c|c|}
\hline Site & Density & Range & Method & Source \\
\hline Tabin Wildlife Reserve, Malaysia & 8 & $8-17$ & Capture-recapture & Wilting et al. (2006) \\
\hline Danum Valley, Malaysia & $4.8-7.3$ & $4.8-7.3$ & Capture-recapture & A. J. Hearn et al. (unpubl.) \\
\hline $\begin{array}{l}\text { Tangkulap-Pinangah Forest Reserve, } \\
\text { Segaliud Lokan Forest Reserve, Malaysia }\end{array}$ & 1 & $\begin{array}{l}0.84 \pm 0.42 \text { and } \\
1.04 \pm 0.58(\mathrm{SE})\end{array}$ & SECR & Wilting et al. (2012) \\
\hline Sabangau Peat-swamp Forest, Indonesia & $0.72-4.41$ & $0.72-4.41$ & Capture-recapture & This study \\
\hline \multicolumn{5}{|l|}{ Malinau Basin } \\
\hline Conservation Area, & 1.9 (primary forest) & $0.7-5.4$ & SECR & Brodie \& Giordano \\
\hline Sabah, Malaysia & 0.8 (whole area) & $0.2-2.6$ & & $(2012)$ \\
\hline
\end{tabular}

\section{Population and activity}

One male (M2) was resident throughout this study, with the other males apparently having shorter residency. It is possible that the core study area is an important part of the territory of M2. The males came within $700 \mathrm{~m}$ of the base camp and within $500 \mathrm{~m}$ of the forest edge, whereas the female was 1.5 to $2.76 \mathrm{~km}$ from the forest edge. The presence of humans in this area may have an impact on the presence of females, but even when the cameras were placed $12 \mathrm{~km}$ from camp, no females were detected. Males clearly did not occupy exclusive ranges, as we had photographs of multiple different males at the same location, indicating overlapping home ranges and that males clearly tolerate each other; only 1 male was shown to overlap with a female. We have detected males moving across $10.8 \mathrm{~km}$ with $8 \mathrm{~d}$ between detections; thus this probably cannot be interpreted as a range or seasonal shift.

There are several hypotheses for the small number of female clouded leopards detected during the $3 \mathrm{mo}$ survey windows. Females are smaller than males and have sole responsibility for raising cubs; therefore, our current hypotheses as to the lack of photo detections of females are as follows. (1) We strongly suspect that the females are staying well away from any human disturbance, as all cameras are on trails and within the research areas/areas where humans are encroaching. (2) Females are perhaps staying away from high concentrations of males, as males may pose a threat to newborn cubs e.g. due to either the risk of infanticide or to avoid inter-sexual competition. (3) Females are staying away from high concentrations of males as they cannot compete for prey with so many larger males present. (4) The selectively logged/disturbed nature of the study locations renders them unsuitable for denning cubs so the females do not come there.

Limitations of this study include the small size of the core survey area (due to the inaccessibility of the study site) and low recapture rates (due to the likelihood that the clouded leopards' home ranges are large relative to the grid). Additionally, given the small survey area, different individual cats were resident in the study area at different times, making the data analysis for density in 3 mo blocks problematic; in no block were all 6 identified individuals detected on the cameras (see Table 2). Despite these limitations, the results (especially the lower end) are more or less in line with previous estimates. Sample sizes of $\sim 10$ to 20 individuals, probably all that is it practicable to achieve for an elusive carnivore in a remote, impenetrable environment, are problematic using capture-recapture closed population models (Otis et al. 1978, White et al. 1982).

\section{Hunting}

In neither the semi-formal interviews and questionnaires nor in general conversation with local people (S. M. Cheyne pers. obs.) was there any mention of clouded leopard skins being used in ceremonies, as has been reported in Malaysian Borneo (Rabinowitz et al. 1987). We conclude that, in this area, direct hunting and/or persecution is not a substantial threat to clouded leopards (Wilting et al. 2006). However, the interviews confirmed that hunters target potential clouded leopard prey (mouse deer, Sambar deer and bearded pigs). Although hunting was not the main source of income for any respondents, 10 to $20 \%$ of each village are engaged in hunting in any given month, with an increase in hunting activity over the dry season. People included fishing as hunting as this is removal of wild animals for human use/ consumption. Population estimates for the villages around the study area are not available and thus more information is needed to elucidate the hunting intensity. The interviewees did not mention muntjac (Muntiacus spp.) and greater mouse deer, but the 
local people do not distinguish between species of mouse deer and may have subsumed muntjac with them.

\section{CONCLUSIONS}

This is the first population study for this threatened felid in any peat-swamp forest, although we have been at pains to emphasise the methodological caveats. We conclude that even with preliminary density range estimates of only 0.72 to 4.41 ind. per $100 \mathrm{~km}^{2}$, peat forest (of which there are an estimated $68000 \mathrm{~km}^{2}$ in Indonesian Borneo; Page et al. 1997, 1999, Cheyne \& Macdonald 2011), may be more important to clouded leopard conservation than previously supposed. If our evidence is typical, then by extrapolation, the totality of peat forest in Indonesian Borneo might harbour a significant population of clouded leopards. Local surveys suggest that hunting pressure is relatively low, and thus habitat loss and fragmentation are likely to be the greatest threats.

Acknowledgements. S.M.C. was funded through a grant to D.W.M. from the Recanati-Kaplan Foundation and by the Clouded Leopard Project/Point Defiance Zoo and Aquarium. S.M.C. and D.W.M.'s work on Bornean felids is part of the WildCRU/Panthera collaboration, and was carried out within the OuTrop-CIMTROP multi-disciplinary research project in the northern Sabangau forest, Central Kalimantan, Indonesia. We gratefully acknowledge the invaluable contribution of all the researchers and staff that assisted with the project: Adul, Aman, Ramadhan, Santiano, Twentinolosa, Y. Kuswanto, K. Jeffers, L. Thompson, A. Höing, R. Chadwick and the OuTrop team. We gratefully thank CIMTROP for sponsoring our research and providing invaluable logistical support. We thank the Indonesian Ministry of Science and Technology (RISTEK) and Director General of Nature Conservation (PHKA) for permission to carry out research in Indonesia. We are very grateful to the editor, 3 anonymous reviewers and to L. Hunter, A. Gopalaswamy, A. Hearn and J. Ross for invaluable comments on earlier drafts of this manuscript.

\section{LITERATURE CITED}

Aldhous P (2004) Borneo is burning. Nature 432:144-146

Brodie J, Giordano A (2012) Density of the Vulnerable Sunda clouded leopard Neofelis diardi in a protected area in Sabah, Malaysian Borneo. Oryx 46(3):427-430

Burnham D, Bearder SK, Cheyne SM, Dunbar RI, Macdonald DW (2013) Predation by mammalian carnivores on nocturnal primates: Is the lack of evidence support for the effectiveness of nocturnality as an anti-predator strategy? Folia Primatol 83:236-251

Chambers R (1994) The origins and practice of participatory rural appraisal. World Dev 22:953-969
Cheyne SM (2010) Behavioural ecology and socio-biology of gibbons (Hylobates albibarbis) in a degraded peatswamp forest. In: Supriatna J, Gursky SL (eds) Indonesian primates. Springer, New York, NY, p 121-156

> Cheyne SM, Macdonald DW (2011) Wild felid diversity and activity patterns in Sabangau peat-swamp forest, Indonesian Borneo. Oryx 45:119-124

> Cheyne SM, Thompson CJH, Phillips AC, Hill RMC, Limin SH (2008) Density and population estimate of gibbons (Hylobates albibarbis) in the Sabangau Catchment, Central Kalimantan, Indonesia. Primates 49:50-56

Cheyne SM, Zrust M, Hoeing A, Houlihan PR, Rowland D, Rahmania M, Breslin K (2012) Barito River Initiative for Nature Conservation and Communities (BRINCC) preliminary report. BRINCC Expedition, Palangka Raya

Gordon $\mathrm{CH}$, Stewart EAM (2007) The use of logging roads by a solitary felid, the clouded leopard. Cat News 47:12-13

Grassman LI, Tewes ME, Silvy NJ, Kreetiyutanont K (2005) Ecology of three sympatric felids in a mixed evergreen forest in north-central Thailand. J Mammal 86:29-38

Harrison ME, Cheyne SM, Darma F, Ribowo DA, Limin SH, Struebig MJ (2011) Hunting of flying foxes and perception of disease risk in Indonesian Borneo. Biol Conserv 144:2441-2449

Hearn AJ, Ross J, Pamin D, Bernard H, Hunter L, Macdonald DW (2013) Insights into the spatial and temporal ecology of the Sunda clouded leopard Neofelis diardi. Raffles Bull Zool 61(2):871-875

IUCN (2008) Red List of Threatened Species. www. iucnredlist.org

Johns AD (1985) Selective logging and wildlife conservation in tropical rainforest: problems and recommendations. Biol Conserv 31:355-375

Johns AD (1988) Effects of 'selective' timber extraction on rain forest structure and composition and some consequences for frugivores and folivores. Biotropica 20:31-37

> Karanth KU, Nichols JD (1998) Estimation of tiger densities in India using photographic captures and recaptures. Ecology 79(8):2852-2862

Kerlinger FN (1986) Foundations of behavioral research. Holt, Rinehart and Winston Inc., Forth Worth, TX

> Koh LP, Wilcove DS (2007) Cashing in palm oil for conservation. Nature 448:993-994

Lynam AJ, Rabinowitz AR, Myint T, Maung M, Latt K, Po ST (2009) Estimating abundance with sparse data: tigers in northern Myanmar. Popul Ecol 51:115-121

Maffei L, Noss AJ, Cuéllar E, Rumiz DI (2005) Ocelot (Felis pardalis) population densities, activity, and ranging behaviour in the dry forests of eastern Bolivia: data from camera trapping. J Trop Ecol 21:349-353

> Morrogh-Bernard H, Husson S, Page SE, Rieley JO (2003) Population status of the Bornean orang-utan (Pongo pygmaeus) in the Sebangau peat swamp forest, Central Kalimantan, Indonesia. Biol Conserv 110:141-152

Nowell K, Jackson P (1996) Wild cats. Status survey and conservation action plan. IUCN, Gland

Otis DL, Burnham KP, White GC, Anderson DR (1978) Statistical inference from capture data on closed animal populations. Wildl Monogr 62:1-135

Page SE, Rieley JO, Doody K, Hodgson S and others (1997) Biodiversity of tropical peat swamp forest: a case study of animal diversity in the Sungai Sebangau catchment of Central Kalimantan, Indonesia. In: Rieley JO, Page SE (eds) Tropical peatlands. Samara Publishing Limited, Cardigan, p 231-242 
Page SE, Rieley JO, Shotyk ØW, Weiss D (1999) Interdependence of peat and vegetation in a tropical peat swamp forest. Philos Trans R Soc Lond B Biol Sci 354: 1885-1897

Pantel S, Yun CS (eds) (2009) Proc Workshop on Trade and Conservation of Pangolins Native to South and Southeast Asia. 30 June-2 Jul 2008, Singapore. TRAFFIC Southeast Asia, Petaling Jaya, Selangor

Povey K, Howard JG, Sunarto, Priatna D and others (2009) Clouded Leopard and Small Felid Conservation Summit Final Rep. IUCN/SSC Conservation Breeding Specialist Group, Apple Valley, MN, and Bangkok

Rabinowitz A, Andau P, Chai PPK (1987) The clouded leopard in Malaysian Borneo. Oryx 21:107-111

Rautner M (2005) Borneo: treasure island at risk. WWF Germany, Frankfurt

Rowcliffe JM, Carbone C (2008) Surveys using camera traps: Are we looking to a brighter future? Anim Conserv 11:185-186

Rowcliffe JM, Field J, Turvey ST, Carbone C (2008) Estimating animal density using camera traps without the need for individual recognition. J Appl Ecol 45:1228-1236

Shepherd CR, Nijman V (2008) The wild cat trade in Myanmar. TRAFFIC Southeast Asia, Petaling Jaya, Selangor

Shepherd PA, Rieley JO, Page SE (1997) The relationship between forest structure and peat characteristics in the upper catchment of the Sungai Sebangau, Central Kalimantan. In: Rieley JO, Page SE (eds) Biodiversity and sustainability of tropical peatlands. Samara Publishing, Cardigan, p 191-210

Editorial responsibility: Al Glen, Lincoln, New Zealand
Silver SC, Ostro LET, Marsh LK, Maffei L and others (2004) The use of camera traps for estimating jaguar Panthera onca abundance and density using capture/recapture analysis. Oryx 38:148-154

Soisalo MK, Cavalcanti SMC (2006) Estimating the density of a jaguar population in the Brazilian Pantanal using camera-traps and capture-recapture sampling in combination with GPS radio-telemetry. Biol Conserv 129: 487-496

Struebig MJ, Harrison ME, Cheyne SM, Limin SH (2007) Intensive hunting of large flying-foxes (Pteropus vampyrus natunae) in the Sebangau Catchment, Central Kalimantan, Indonesian Borneo. Oryx 41:1-4

White GC, Anderson DR, Burnham KP, Otis DL (1982) Capture-recapture and removal methods for sampling closed populations. LA-8787-NERP. Los Alamos National Laboratory, Los Alamos, NM

Wilting A, Fischer F, Bakar SA, Linsenmair KE (2006) Clouded leopards, the secretive top-carnivore of SouthEast Asian rainforests: their distribution, status and conservation needs in Sabah, Malaysia. BMC Ecol 6:16

Wilting A, Cord A, Hearn AJ, Hesse D and others (2010) Modelling the species distribution of flat-headed cats (Prionailurus planiceps) an endangered Southeast Asian small felid. PLoS ONE 5:e9612

Wilting A, Mohamed A, Ambu LN, Lagan P, Mannan S, Hofer H, Sollmann R (2012) Density of the Vulnerable Sunda clouded leopard Neofelis diardi in two commercial forest reserves in Sabah, Malaysian Borneo. Oryx 46(3):423-426

Submitted: November 30, 2012; Accepted: June 12, 2013 Proofs received from author(s): September 26, 2013 